\title{
Media Pembelajaran Audio Video Terhadap Kemampuan Pemecahan Masalah Matematika Siswa
}

\author{
Darmawan Harefa ${ }^{1}$, Hestu Tansil Laia ${ }^{2}$ \\ STKIP Nias Selatan \\ e-mail: harefadarmawan@gmail.com, hestutansil@gmail.com
}

Received: 12 Januari 2021; Revised: 26 Februari 2021; Accepted: 28 April 2021

DOI: http://dx.doi.org/10.37905/aksara.7.2.329-338.2021

\begin{abstract}
Abstrak
Penelitian ini bertujuan untuk mengetahui pengaruh media pembelajaran audio video terhadap kemampuan pemecahan masalah matematika siswa. Penelitian ini menggunakan pendekatan kuantitatif dengan metode quasi eksperiment Populasi penelitian ini adalah seluruh siswa kelas VIII SMP di desa Hiliganowo yang berjumlah 23 orang. Data dianalisis dengan menggunakan uji t-test sampel related untuk menguji hipotesis. Penelitian menunjukkan dengan penggunaan media pembelajaran audio video siswa lebih tertarik dan mudah memahami materi yang disampaikan, kemampuan pemecahan masalah matematika siswa baik. Berdasarkan hasil uji hipotesis diperoleh $t_{\text {hitung }}>t_{\text {tabel }}(4,516>1,721)$. Maka dapat disimpulkan bahwa media pembelajaran audio video mempengaruhi kemampuan pemecahan masalah matematika siswa.
\end{abstract}

Kata Kunci

Media, Audio, Video, Kemampuan Pemecahan Masalah, Matematika

\section{Abstract}

This study aims to see effect audio video learning media on students' mathematical problem abilities. This study used quantitative approach with quasi-experimental method. Population study of class VIII SMP in Hiliganowo village who added 23 people. The data were analyzed using the associated sample t-test to test the hypothesis. Research shows that with the use of audio video learning media students are more interested and easier to understand the material presented, the ability of students' math problems well. Based the results of hypothesis testing, it is obtained that tcount> ttable (4.516> 1.721). So can be denied the audio video learning media affects the ability students' math problems.

Keywords

Media, Audio, Video, Problem Solving Ability, Mathematics

\section{Pendahuluan}

Kehidupan manusia tidak dapat dipungkiri dalam menjalani kesehariannya selalu menghadapi berbagai masalah. (Harefa, 2020a) menyatakan bahwa masalah (problem) merupakan bagian dari kehidupan manusia baik bersumber dari dalam diri maupun lingkungan sekitar. Hampir setiap hari manusia berhadapan dengan suatu masalah yang perlu dicari jalan keluarnya. Adanya permasalahan tersebut secara tidak langsung 
menjadikan kemampuan pemecahan masalah sebagai aktivitas dasar manusia untuk dapat bertahan hidup. Oleh karena itu, setiap individu diharapkan mampu berperan sebagai pemecah masalah yang handal untuk dapat mempertahankan kehidupannya.

Masalah tidak hanya dihadapi oleh orang dewasa, tetapi siswa juga menghadapi permasalahan dalam lingkungan belajarnya. Permasalahan yang dimaksud berupa soal maupun tugas yang dapat dimengerti namun menantang untuk diselesaikan oleh siswa. Selain itu, soal tersebut tentunya tidak mudah untuk diselesaikan dengan prosedur rutin yang telah diketahui oleh siswa. Oleh karena itu, salah satu tujuan pendidikan pada hakekatnya adalah suatu proses terus menerus manusia untuk menanggulangi masalahmasalah yang dihadapi sepanjang hayat. Karena itu siswa harus benar-benar dilatih dan dibiasakan berpikir secara mandiri dalam mencari penyelesaian masalah tersebut.

Perkataan mathematike berhubungan sangat erat dengan sebuah kata lain yang serupa, yaitu mathanein yang mengandung arti belajar atau berpikir. Menurut (Hendriana, 2018) matematika adalah "ilmu tentang pola yang perlu dikembangkan lebih lanjut di mana memuat pengamatan dan pengkodean melalui representasi yang abstrak, dan peraturan dalam dunia simbol dan objek". Artinya, matematika itu berhubungan dengan pola, objeknya abstrak dan dipenuhi dengan simbol-simbol.

Selain itu, (Laia, 2019) menyatakan bahwa matematika adalah "ilmu tentang logika, mengenai bentuk, susunan, besaran, dan konsep-konsep yang berhubungan satu dengan lainnya. Matematika terbagi dari empat besar bagian yaitu aritmetika, aljabar, analisis dan geometri”. Artinya, matematika mencakup berbagai bidang dan tidak hanya berhubungan berpikir dan penalaran tetapi juga tentang logika, konsep, susunan dan besaran. Salah satu pembelajaran di sekolah yang selalu menjadi masalah bagi seorang siswa adalah pembelajaran matematika (Harefa, D., 2020a). Bagi siswa, pembelajaran matematika merupakan pembelajaran yang susah dipahami dan hanya orang-orang tertentu yang mampu mempelajarinya. Apalagi objeknya yang abstrak sehingga ada beberapa materi matematika yang sulit diberikan contoh penerapannya pada kehidupan sehrai-hari siswa. Oleh karena itu, siswa banyak yang menghindari pembelajaran matematika dan tidak ingin belajar matematika. Siswa tidak memahami bahwa pada dasarnya kemampuan pemecahan masalah dapat dikembangkan melalui pembelajaran matematika (Harefa, 2017).

Kemampuan pemecahan masalah matematika penting untuk dilakukan oleh siswa agar memberikan nilai positif terhadap intelektual siswa dalam pengembangan kemampuan pemecahan masalah matematika yang mana merupakan tuntutan dasar yang harus dikuasai oleh siswa. Artinya, siswa perlu dilatih dan dibiasakan untuk menyelesaikan soal-soal pemecahan masalah matematika. Tuntutan akan kemampuan pemecahan masalah selalu dipertegas dalam setiap kurikulum yang ada sebagai kompetensi dasar yang harus dikembangkan dan diintegrasikan pada sejumlah materi yang sesuai. Pentingnya kemampuan penyelesaian masalah oleh siswa dalam matematika, maka menjadikan kemampuan menyelesaikan masalah merupakan tujuan umum pengajaran matematika. Penyelesaian masalah yang meliputi metode, prosedur, dan strategi merupakan proses inti dan utama dalam kurikulum matematika.

Pada kenyataannya, kemampuan pemecahan masalah matematika belum dikuasai sepenuhnya oleh siswa. Hal ini sesuai dengan hasil studi pendahuluan yang peneliti lakukan di desa Hiliganowo khususnya bagi siswa SMP kelas VIII melalui kegiatan tanya jawab secara langsung kepada siswa tentang tanggapannya dalam memecahkan 
suatu masalah dan khususnya dalam menyelesaikan soal-soal pemecahan masalah matematika. hal ini disebabkan karena siswa tidak terbiasa menyelesaikan soal-soal pemecahan masalah. Misalnya, bagaimana siswa memahami suatu masalah, bagaimana menyelesaikan suatu masalah, bagaimana prosedur penyelesaian masalah dan apakah teliti terhadap jawaban yang diperoleh. Ternyata siswa tidak mampu menyelesaikan soal yang mereka anggap sulit dan hanya soal-soal yang sesuai dengan contoh yang diberikan guru saja yang bisa mereka selesaikan. Selain itu, kurangnya keinginan siswa dalam pembelajaran, persepsi siswa yang salah terhadap pembelajaran matematika, siswa kurang memahami materi yang diajarkan, siswa tidak mampu memahami masalah yang diajukan, siswa mengabaikan penggunaan media pembelajaran. Siswa belum terbiasa dalam menyelesaikan soal-soal matematika yang berbentuk pemecahan masalah dan hanya bergantung pada prosedur yang diajarkan oleh guru.

Permasalahan di atas, jika diabaikan akan berpengaruh terhadap hasil belajar matematika siswa. Tujuan pembelajaran yang diharapkan tidak tercapai dan secara umum kemampuan-kemampuan yang diharapkan dikuasai oleh siswa dalam pembelajaran tidak akan tercapai. Oleh karena itu, perlu upaya mengatasi masalah terkait kemampuan pemecahan masalah matematika siswa, dimana merupakan tanggung jawab guru untuk memikirkan dan melaksanakan pembelajaran yang sesuai dengan kebutuhan siswa dan melaksanakan proses pembelajaran yang lebih bermakna dan menarik. Peneliti memberikan solusi dengan menggunakan media pembelajaran video audio. Penggunaan media pembelajaran memberikan dampak yang cukup besar kepada siswa dalam memahami konsep materi yang diajarkan. Siswa akan lebih mudah memahami jika dapat dilihat dan dipegang secara langsung objek yang dibicarakan. Media pembelajaran tersebut adalah media pembelajaran visual. Media pembelajaran visual ini memiliki manfaat untuk memudahkan menjelaskan konsep-konsep yang bersifat abstrak dan sulit dijelaskan secara langsung kepada siswa, menghadirkan replika objek yang sedang dibicarakan sehingga siswa lebih mengenal objek tersebut. Dengan demikian, diharapkan hasil belajar siswa dapat meningkat.

Secara sederhana, media dapat dipahami sebagai segala bentuk atau saluran yang digunakan untuk menyampaikan pesan atau informasi kepada pihak lainnya. (Darmawan, 2020) menyatakan bahwa media pembelajaran adalah berbagai jenis komponen dalam lingkungan peserta didik yang dapat memotivasi peserta didik untuk belajar. Penggunaan media dapat membuat siswa tertarik mengikuti pembelajaran. Hal ini senada dengan pendapat yang menyatakan bahwa media merupakan sumber belajar yang berisikan pesan atau materi pelajaran yang dibuat secara menarik dalam bentuk kombinasi gambar, teks, gerak, dan animasi yang disesuaikan dengan usia peserta didik sehingga pembelajaran akan menyenangkan dan tidak menjenuhkan. Misalnya, siswa yang memiliki ketertarikan terhadap warna maka dapat diberikan media dengan warna yang menarik.

Menurut (Susilana, 2017) "Media merupakan salah satu faktor penentu keberhasilan pembelajaran. Melalui media proses pembelajaran dapat lebih menarik dan menyenangkan". Misalnya, siswa yang memiliki ketertarikan terhadap warna maka dapat diberikan media dengan warna yang menarik. Begitu pula halnya dengan siswa yang senang dengan bentuk atau objek maka dapat diberikan media yang sesuai seperti media balok bangun ruang atau media gambar bangun datar dan bangun ruang. 
(Djamarah, 2006) menyatakan bahwa media sebagai alat bantu apa saja yang dapat dijadikan sebagai penyalur pesan guna mencapai tujuan pengajaran.

(Hamalik \& Oemar Hamalik, 2012) mengemukakan "Media pembelajaran dalam proses belajar mengajar dapat membangkitkan keinginan dan minat yang baru, membangkitkan motivasi dan rangsangan kegiatan belajar, dan bahkan membawa pengaruh-pengaruh psikologis terhadap siswa". (Arsyad, 2017) menyatakan bahwa media pembelajaran memiliki cakupan yang sangat luas, yaitu termasuk manusia, materi atau kajian yang membangun suatu kondisi yang membuat peserta didik mampu memperoleh pengetahuan, ketrampilan, atau sikap. Artinya, media bukanlah hanya sebatas gambar, foto, alat elektronik dan sebagainya seperti yang dibayangkan selama ini, namun jauh lebih luas cakupannya termasuk manusia, lingkungan dan yang lainnya. Media merupakan suatu yang bersifat menyalurkan pesan dan dapat merangsang pikiran, perasaan, dan kemauan audien (siswa) sehingga dapat mendorong terjadinya proses belajar pada dirinya"

Begitu pula halnya dengan siswa yang senang dengan bentuk atau objek maka dapat diberikan media yang sesuai seperti media balok bangun ruang atau media gambar bangun datar dan bangun ruang. Dengan demikian pemanfaatan media pembelajaran yang tepat merupakan faktor yang mendukung aktivitas belajar sehingga proses pembelajaran yang disampaikan dapat berjalan dengan baik dan apa bila tidak adanya pemanfaatan media pembelajaran, maka dapat diprediksi bahwa siswa akan mendapat kesulitan di dalam memahami materi pembelajaran yang disampaikan.

\section{Metode}

Jenis penelitian ini adalah penelitian eksperimen. Metode yang digunakan dalam penelitian ini adalah metode penelitian kuantitatif. Pada penelitian ini, pembelajaran dilaksanakan melalui media pembelajaran audio video. Selanjutnya, setelah pembelajaran selesai siswa akan diberikan tes kemampuan pemecahan masalah matematika.

Desain penelitian yang digunakan adalah desain eksperimen pre experimental design dengan bentuk one group pretest posttest design. One Groups Pretest-Posttest Design yaitu desain penelitian yang terdapat pretest sebelum diberi perlakuan dan posttest setelah diberi perlakuan (Surur, M., 2020). Dengan demikian dapat diketahui lebih akurat, karena dapat membandingkan dengan diadakan sebelum diberi perlakuan Dalam desain penelitian ini, sebelum diberikan perlakuan terlebih dahulu diberikan pretest kepada subjek penelitian, kemudian diberikan perlakuan dengan menggunakan media pembelajaran audio video dan terakhir diberikan posttest.

Tabel. 1. Desain Penelitian One Group Pretest Posttest Design

\begin{tabular}{ccc}
\hline Pretest & Perlakuan & PostTest \\
\hline $\mathrm{O}_{1}$ & $X$ & $\mathrm{O}_{2}$ \\
\hline
\end{tabular}

Sumber :(Sugiyono, 2012)

Keterangan:

$\mathrm{O}_{1}$ : Nilai Pretest (pemberian Pretest)

$\mathrm{X}$ : Pemberian perlakuan (Media Pembelajaran Audio Video)

$\mathrm{O}_{2}$ : Nilai Posttest (pemberian Posttest) 


\section{HASIL DAN PEMBAHASAN}

\section{Hasil}

Setelah pemberian pretest, kemudian dilanjutkan dengan pemberian perlakuan pada siswa. Perlakuan diberikan yakni dengan memberikan video mengajar dengan cara mengirimkan ke handphone siswa atau dengan memutar langsung melalui laptop peneliti. Selanjutnya, diberikan postest yang selanjutnya diolah dan dianalisis.

\section{a. Hasil Pretest}

Berdasarkan data nilai pretest pada lampiran maka dapat ditentukan nilai ratarata, standar deviasi dan varians dari data tersebut (Harefa, 2020).

Nilai rata-rata: $\bar{x}=\frac{\sum x i}{n}, \bar{x}=\frac{1334}{23}, \bar{x}=58$ Jadi, rata-rata hasil pretest sebesar 58 .

Standar deviasi dan varians: $\mathrm{s}^{2}=\frac{n \sum x_{i}^{\mathrm{n}}-\left(\sum x_{i}\right)^{2}}{n(n-1)}, \mathrm{s}^{2}=\frac{23(82946)-1779556}{23(23-1)}, \mathrm{s}^{2}=\frac{128202}{506} \mathrm{~s}^{2}=$ $253,35, \mathrm{~s}=15,92$

Jadi, varians hasil tes awal sebesar 253,36 dan standar deviasinya sebesar 15,92.

\section{b. Hasil Posttest}

Berdasarkan data nilai posttest pada lampiran yang selajutnya diolah untuk mendapatkan nilai rata-rata, standar deviasi dan varians.

Nila rata-rata: $\bar{x}=\frac{\sum x i}{n}, \bar{x}=\frac{1495}{23}, \bar{x}=65$, Jadi, nilai rata-rata posttest sebesar 65 .

Standar deviasi dan varians:

$\mathrm{s}^{2}=\frac{n \sum x_{i}^{2}-\left(\sum x_{i}\right)^{2}}{n(n-1)}, \mathrm{s}^{2}=\frac{23(100409)-2235025}{23(23-1)}, \mathrm{s}^{2}=\frac{74382}{506}, \mathrm{~s}^{2}=147, \mathrm{~s}=12,12$

Jadi, varians hasil postets sebesar 147 dan standar deviasinya sebesar 12,12.

Gambar 1. Diagram Nilai Rata-rata, Standar Deviasi dan Varians Pretest dan Postest

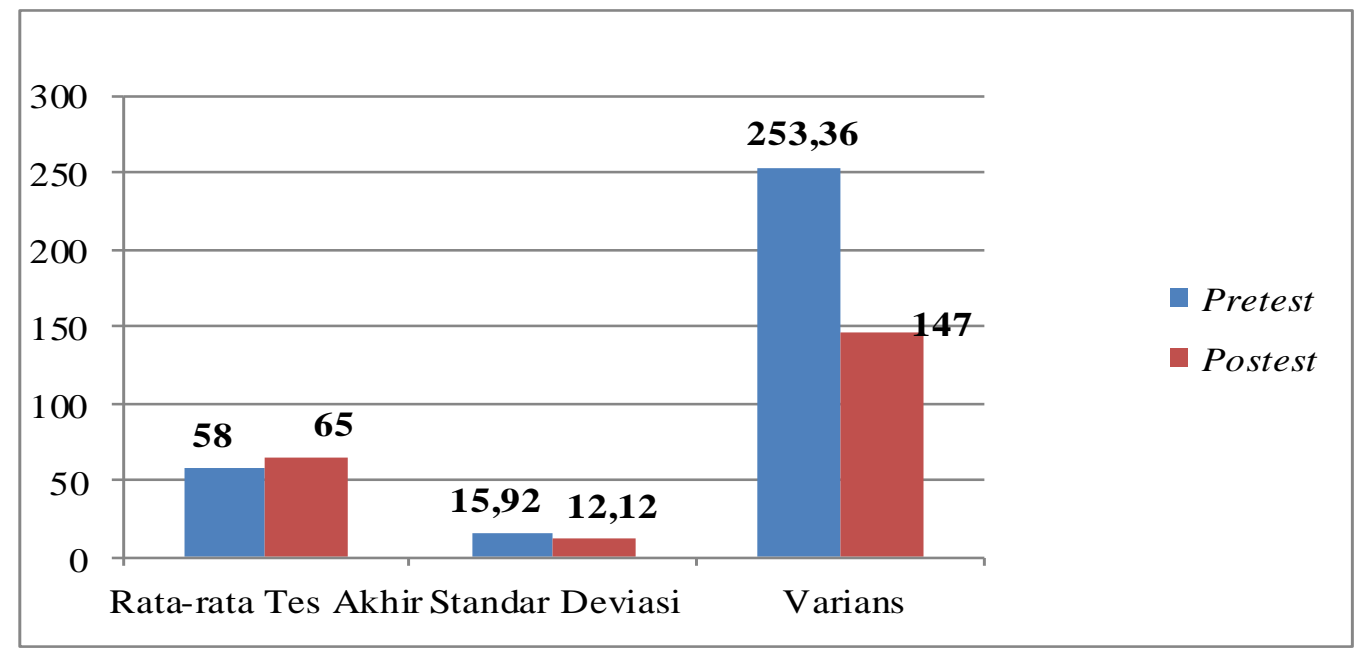

Sumber :Peneliti

\section{Uji Koefisien Korelasi $(r)$}

Sebelum melakukan pengujian hipotesis, terlebih dahulu dihitung nilai koefisien korelasi antara kedua variabel penelitian. Hal ini diperlukan karena dalam perhitungan uji hipotesis diperlukan nilai koefisien korelasi (r) (Harefa, D., 2020). 
Berdasarkan data hasil pretest dan posttest yang ada pada lampiran, maka diperoleh nilai-nilai berikut:

$$
\begin{array}{lll}
\mathrm{N}=23 & \sum \mathrm{X}=1334 & \sum \mathrm{Y}=1495 \\
\sum \mathrm{XY}=90505 & \sum \mathrm{X} \cdot \sum \mathrm{Y}=1994330 & \sum \mathrm{X}^{2}=82946 \\
\sum \mathrm{Y}^{2}=100409 \quad\left(\sum \mathrm{X}\right)^{2}=1779556 & \left(\sum \mathrm{Y}\right)^{2}=2235025 \\
\text { Uji koefisien korelasi: } & \\
\mathrm{r}=\frac{N \sum X Y-\left(\sum X\right)\left(\sum Y\right)}{\sqrt{\left[\left(N \sum X^{2}-\left(\sum X\right)^{2}\right\}\left[N \sum Y^{2}-\left(\sum Y\right)^{2}\right]\right.}}, \mathrm{r}=\frac{23.90505-(1334)(1495)}{\sqrt{(23(82946)-(1779556)\}[23(100409)-(2235025)]}} \\
\mathrm{r}=\frac{87285}{\sqrt{(128202)(74382)}}, \mathrm{r}=\frac{87285}{\sqrt{9535921164}}, \mathrm{r}=\frac{87285}{97652,0413}, \mathrm{r}=0,894 \\
\text { Jadi, nilai koefisien korelasi } r \text { adalah } 0,894 .
\end{array}
$$

\section{Uji Hipotesis}

Untuk membuktikan hipotesis penelitian ini maka dilakukan pengujian hipotesis. Data yang digunakan untuk pengujian hipotesis adalah data hasil pretest dan posttest. Berdasarkan data hasil tes akhir dari kedua kelas sampel penelitian, diperoleh nilai ratarata $\left(\bar{x}_{1}\right)$ untuk postest sebesar 65 , standar deviasinya (s) sebesar 12,12 dan variansnya $\left(\mathrm{s}^{2}\right)$ sebesar 147. Sedangkan untuk pretest, rata-rata $\left(\bar{x}_{2}\right)$ sebesar 58; standar deviasinya (s) 15,92 dan variansnya $\left(\mathrm{s}^{2}\right)$ sebesar 253,36. Nila koefisien korelasi $(r)$ sebesar 0,894.

Selanjutnya, Untuk mengetahui $t_{\text {hitung }}$ digunakan rumus:

$$
\begin{aligned}
& t=\frac{\bar{x}_{1}-\bar{x}_{z}}{\sqrt{\frac{s_{1}^{2}}{n_{1}}+\frac{s_{2}^{2}}{n_{2}}-2 r\left(\frac{s_{1}}{\sqrt{n_{1}}}\right)\left(\frac{s_{2}}{\sqrt{n_{2}}}\right)}}, t=\frac{65-58}{\sqrt{\frac{147}{28}+\frac{258,85}{28}-2(0,894)\left(\frac{1 n_{1}, 12}{\sqrt{28}}\right)\left(\frac{15,92}{\sqrt{28}}\right)}}, t=\frac{7}{\sqrt{17,405-15,000}} \\
& t=\frac{7}{\sqrt{2,405}}, t=\frac{7}{1,55}, t=4,516
\end{aligned}
$$

Jadi, nilai $t_{\text {hitung }}$ adalah 4,516.

Dari hasil perhitungan di atas diperoleh nilai $t_{\text {hitung }}$ sebesar 4,516 dan kemudian dikonsultasikan pada daftar $t_{\text {tabal }}$ dengan taraf signifikan 0,05 dan $d k=n_{1}-2=23-2=21$. Selanjutnya, nilai $t_{\text {tabel }}$ ditentukan dengan $\mathrm{dk}=23$ yaitu $t_{\text {tabel }}=1,721$, sehingga $t_{\text {hitung }}>t_{\text {tabel }}$ yaitu 4,516>1,721 atau $t_{\text {hitung }}=4,516$ tidak terletak pada interval: $-1,721 \leq \mathrm{t} \leq 1,721$ yang berarti $H_{0}$ ditolak dan $H_{a}$ diterima pada taraf signifikan 0,05. Dari hasil tersebut, dapat disimpulkan bahwa ada pengaruh media pembelajaran audio video terhadap kemampuan pemecahan masalah matematika siswa.

\section{Temuan Penelitian}

Temuan yang diperoleh peneliti pada saat melaksanakan penelitian dengan menggunakan media pembelajaran audio video yaitu 1) siswa lebih mudah memahami materi yang disampaikan, 2) siswa membangun sendiri pengetahuannya melalui kegiatan pengamatan terhadap video pembelajaran, 3) siswa dapat mengulang mempelajari kembali materi yang kurang dipahami dengan memutar kembali video pembelajaran, 4) siswa lebih mudah mengikuti pembelajaran dimana saja, 5) rata-rata nilai tes kemampuan pemecahan masalah matematika siswa sedikit mengalami peningkatan dari tes sebelumnya.

Penggunaan media pembelajaran audio video ini sangat membantu siswa dalam memahami materi statistika yang dipelajari. Siswa tidak hanya mendengarkan penjelasan materi tetapi juga melihat proses bagaimana materi itu dijelaskan secara 
visual, misalnya dalam menyajikan gambar, diagram, grafik dan proses penyelesaian soal pemecahan masalah yang berkaitan dengan materi statistika. Media pembelajaran audio visual membuat pembelajaran itu akan menarik, efektif dan efesien karena peserta didik terutama siswa sekolah dasar masih berfikir konkrit, semua yang guru utarakan atau sampaikan harus dibuktikan sendiri dengan mata mereka.

Selain itu, dari hasil tes yang diberikan rata-rata nilai siswa pada pretest sebesar 58 dan pada posttest sebesar 65. Selanjutnya dilihat dari hasil uji hipotesis dimana nilai $t_{\text {hitung }}>t_{\text {tabel }}(4,516>1,721)$ yang artinya $H_{o}$ ditolak dan $H_{a}$ diterima sehingga disimpulkan bahwa ada pengaruh media pembelajaran audio video terhadap kemampuan pemecahan masalah matematika siswa.

\section{Pembahasan}

Penelitian ini bertujuan untuk mengetahui pengaruh media pembelajaran audio video terhadap kemampuan pemecahan masalah matematika siswa kelas VIII SMP di Desa Hiliganowo Tahun Pembelajaran 2020/2021. Kegiatan pembelajaran biasanya dilaksanakan di sekolah khususnya di kelas, adanya interaksi antara siswa dengan guru dan siswa dengan siswa. Namun, mengingat situasi saat ini dimana seluruh kegiatan pembelajaran dilaksanakan dari rumah. Oleh karena itu, salah satu bentuk upaya yang dapat dilakukan oleh guru agar tetap dapat melaksanakan pembelajaran adalah dengan menggunakan media pembelajaran audio video. Guru membuat suatu video pembelajaran mengenai materi statistika atau mendownload video dari internet, kemudian mengirimkan atau memberikan kepada siswa untuk dipelajari.

Penggunaan media pembelajaran audio video ini mengajarkan siswa belajar secara mandiri dengan memahami materi yang diajarkan tanpa bertatap muka langsung dengan guru, akan tetapi hanya dengan menonton video pembelajaran yang telah disiapkan oleh guru sebelumnya. Melalui video pembelajaran ini, siswa lebih tertarik untuk belajar karena langsung melihat penjelasan materi statistika melalui video. Hal ini sesuai dengan pendapat (Arsyad, 2017) yang menyatakan bahwa apabila dikaitkan antara media audio visual dan pembelajaran maka pembelajaran itu akan menarik, efektif dan efesien karena peserta didik terutama siswa sekolah dasar masih berfikir konkrit, semua yang guru utarakan atau sampaikan harus dibuktikan sendiri dengan mata mereka.

Selain itu, media pembelajaran audio video memberikan pengaruh terhadap peningkatan daya serap atau daya ingat siswa sehingga materi lebih mudah dipahami. Siswa dapat mengulang kembali materi yang kurang dipahami dengan memutar kembali video pembelajaran yang diberikan oleh guru. Senada dengan itu, (Harefa, 2019) menyatakan bahwa salah satu fungsi media pembelajaran adalah menarik perhatian siswa dengan menampilkan sesuatu yang menarik dari media tersebut. (Sudjana, 2014) mengemukakan manfaat media pembelajaran dalam proses belajar siswa yaitu pembelajaran akan lebih menarik perhatian siswa sehingga dapat menumbuhkan motivasi belajar.

Berdasarkan hasil tes yang diberikan oleh peneliti diperoleh rata-rata nilai siswa mengalami peningkatan dimana pada rata-rata nilai pretest sebesar 58 dan rata-rata nilai posttest sebesar 65 . Selanjutnya dilihat dari hasil uji hipotesis dimana nilai $t_{\text {hitung }}>t_{\text {tabel }}$ $(4,516>1,721)$ yang artinya $\mathrm{H}_{\mathrm{o}}$ ditolak dan $\mathrm{H}_{\mathrm{a}}$ diterima sehingga disimpulkan bahwa ada pengaruh media pembelajaran audio video terhadap kemampuan pemecahan masalah matematika siswa. Penelitian yang serupa juga pernah diteliti oleh (Susilawati, 
2017) dengan judul penelitian "Pengaruh Media Kapone (Kancing Positif Negatif) Terhadap Kemampuan Pemahaman dan Pemecahan Masalah Matematis Siswa Pada Materi Bilangan Bulat" menyimpulkan bahwa pembelajaran menggunakan media kapone (kancing positif negatif) secara signifikan lebih baik daripada pembelajaran konvensional dalam materi penjumlahan dan pengurangan bilangan bulat untuk meningkatkan kemampuan pemahaman dan pemecahan masalah matematis siswa.

\section{Simpulan}

Berdasarkan hasil pengolahan data penelitian dan pembahasan hasil penelitian yang telah diuraikan, maka dapat disimpulkan bahwa penggunaan media pembelajaran audio visual dapat memengaruhi kemampuan pemecahan masalah matematika siswa. Hal ini karena, siswa lebih memahami materi yang diajarkan dengan melihat langsung secara visual objek materi statistika yang dipelajari. Selain itu, objek yang abstrak lebih ditampilkan menyerupai objek-objek yang lebih konkrit. Siswa dapat mengulang mempelajari kembali materi yang kurang dipahami dengan memutar kembali video pembelajaran

\section{Daftar Pustaka}

Arsyad, A. (2017). Media Pembelajaran. PT.Raja Grafindo Persada.

Darmawan. (2020). PENINGKATAN HASIL BELAJAR SISWA DENGAN PEMBELAJARAN KOOPERATIF MAKE A MATCH PADA APLIKASI JARAK DAN PERPINDAHAN. GEOGRAPHY Jurnal Kajian, Penelitian Dan Pengembangan Pendidikan, 8(1), 1-18.

Djamarah, S. B. (2006). Strategi Belajar Mengajar. PT Rineka Cipta.

Hamalik, O., \& Oemar Hamalik. (2012). Kurikulum dan Pembelajaran. PT Bumi Aksara.

Harefa, D., D. (2020a). Penerapan Model Pembelajaran Cooperatifve Script Untuk Meningkatkan Hasil Belajar Matematika. JKPM (Jurnal Kajian Pendidikan Matematika), 6(1), 13-26.

Harefa, D., D. (2020b). Teori Model Pembelajaran Bahasa Inggris dalam Sains. CV. Insan Cendekia Mandiri.

Harefa, D. (2017). Pengaruh Presepsi Siswa Mengenai Kompetensi Pedagogik Guru Dan Minat belajar Siswa Terhadap Prestasi Belajar Ilmu Pengetahuan Alam (Survey pada SMK Swasta di Wilayah Jakarta Utara). Horison Jurnal Ilmu Pendidikan Dan Lingusitik, 7(2), 49.

Harefa, D. (2019). The Effect Of Guide Note Taking Instructional Model Towards Physics Learning Outcomes On Harmonious Vibrations. JOSAR (Journal of Students Academic Research), 4(1), 131-145.

Harefa, D. (2020a). Pengaruh Antara Motivasi Kerja Guru IPA dan Displin Terhadap Prestasi Kerja. Aksara: Jurnal Ilmu Pendidikan Nonformal, 6(3), 225-240.

Harefa, D. (2020b). Peningkatan Prestasi Rasa Percaya Diri Dan Motivasi Terhadap Kinerja Guru IPA. Media Bina Ilmiah, 13(10), 1773-1786. https://doi.org/https://doi.org/10.33758/mbi.v13i10.592

Hendriana, R. dan S. (2018). Hard Skill dan Soft Skill Matematik Siswa. PT. Refika Aditama.

Laia, H. (2019). HUBUNGAN MOTIVASI BERPRESTASI TERHADAP HASIL 
BELAJAR MATEMATIKA PADA MATERI POKOK OPERASI HITUNG BENTUK ALJABAR TERHADAP SISWAKELAS VII SMP NEGERI 1 TELUKDALAM TAHUN PEMBELAJARAN 2018/2019. Jurnal Education and Development Institut Pendidikan Tapanuli Selatan, 7(4).

Sudjana, N. (2014). Penelitian Hasil Proses Belajar Mengajar. Remaja Rosdakarya. Sugiyono. (2012). Metode Penelitian. Alfabeta.

Surur, M., D. (2020). Effect Of Education Operational Cost On The Education Quality With The School Productivity As Moderating Variable. Psychology and Education Journal, 57(9), 1196-1205.

Susilana, D. (2017). Media Pembelajaran: Hakikat, Pengembangan, Pemanfaatan dan Penilaian. Bandung: CV Wacana Prima.

Susilawati, D. (2017). Pengaruh Media Kapone (Kancing Positif Negatif) Terhadap Kemampuan Pemahaman dan Pemecahan Masalah Matematis Siswa Pada Materi Bilangan Bulat. Jurnal Pena Ilmiah, 2(1). 
